\title{
Short evaluation of eggplant production and variety usage in Romania - short overview and perspectives
}

\section{András KOVÁCS, Levente SZAPPANYOS, Hajnalka LEDÓ DARÁZSI, Zoltán FELFÖLDI, Csanád-Tas SZABÓ}

\author{
Agrosel SRL, Câmpia Turzii, Romania. \\ andras.kovacs@agrosel.ro, levente.szappanyos@agrosel.ro, zoltan.felfoldi@agrosel.ro, \\ csanad.szabo@agrosel.ro, hajnalka.ledo@agrosel.ro
}

Manuscript received Nov. 20, 2016; revised Nov. 30, 2016; Accepted Dec. 02, 2016

\begin{abstract}
Eggplant (Solanum melongena L.) became wide-spread after the First World War in Romania. The most important growing areas of this plant are located in the southern, south-eastern, and south-western parts of Romania and are usually cultivated on open fields as well as in unheated greenhouses. In the past, only Romanian OP varieties were grown. Over the past ten years, requirements of eggplant varieties have increasingly shifted towards productivity, uniformity, and high tolerance to stress factors, diseases, and pests. Therefore, the cultivation of hybrids and the disappearance of Romanian OP cultivars have intensified. Due to monoculture practice, the soil was attacked by pathogens in many areas. As a result, grafting became necessary to be put into practice. Consumption of eggplants is about $4.5 \mathrm{~kg}$ per person per year in Romania and they are consumed in many different ways such as baked, grilled, or as a special cream. Agrosel SRL has gained a significant role in supplying the Romanian vegetable seed market over the past twenty years and has started its own hybrid programme to renew eggplant production in Romania.
\end{abstract}

Keywords: cultivation, breeding programmes, vegetable crop, seed production

Eggplant is a tropical perennial herbaceous plant often cultivated as a half-hardy annual in temperate climates. The species $S$. melongena has been cultivated and regarded as a native in South and East Asia from ancient times. In Europe, it was introduced through the Mediterranean area (first in Greece and Italy) by the Arabs in the early Middle Ages (around 1200) (Singh et al. 2004, Al-Awwam I. 1889). 
In Romania, it was propagated by Greek and Bulgarian gardeners in the $18^{\text {th }}$ century and it became wide-spread after the First World War. In 1992, the cultivated areas of eggplant were 4,500 ha, which has significantly increased to almost 9,500 ha with a 125,000 t yield in the recent years (Echim I. et al. 1983, FAO 2013).

\section{Harvested area and production quantity of Eggplant in ROMANIA 2000-2013}

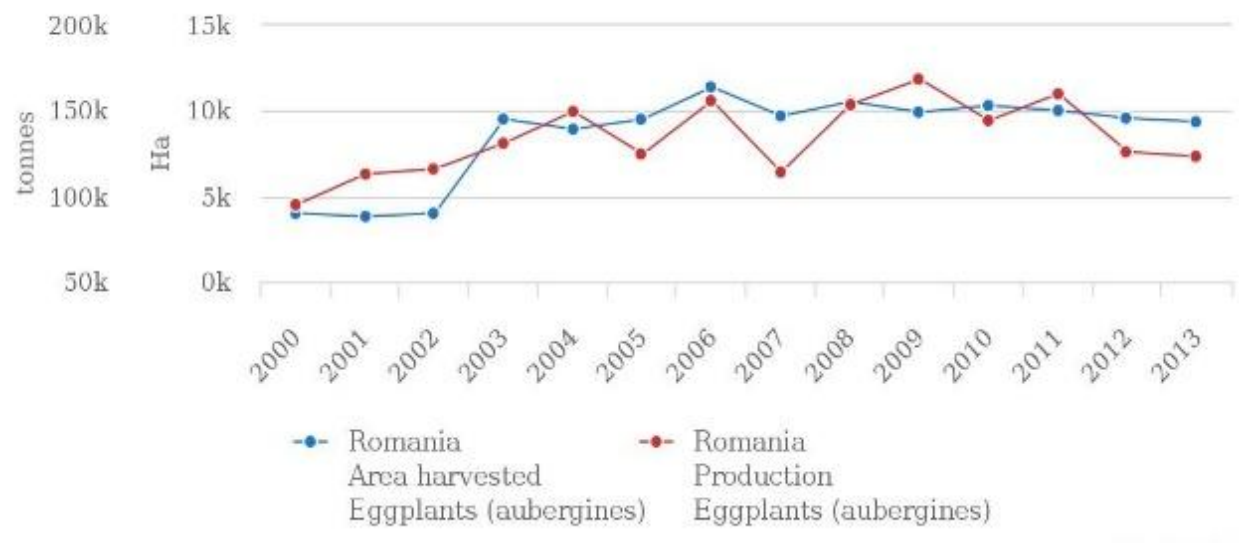

Figure 1. Harvested area and production quantity of eggplant in Romania

(FAO 2016)

The most important growing areas of eggplant are located in the southern, south-eastern, and south-western parts of Romania: Matca-Tecuci, Galaţi; Coşereni, Ialomiţa; Izbiceni-Cilieni, Olt; Vidra, Giurgiu; Seleuşi-Curtici, Arad.

Eggplants are usually cultivated on open fields as well as in unheated greenhouses. For open-field cultivation, nursing time begins with sowing at the end of February and planting time starts when the temperature of the soil reaches a minimum of $14{ }^{\circ} \mathrm{C}$ in $10-15 \mathrm{~cm}$ depth. The harvest begins when the fruit reaches market maturity and a 30-40 t/ha yield can be obtained. To achieve market maturity earlier, plastic tunnels are being used to cover the plants. 


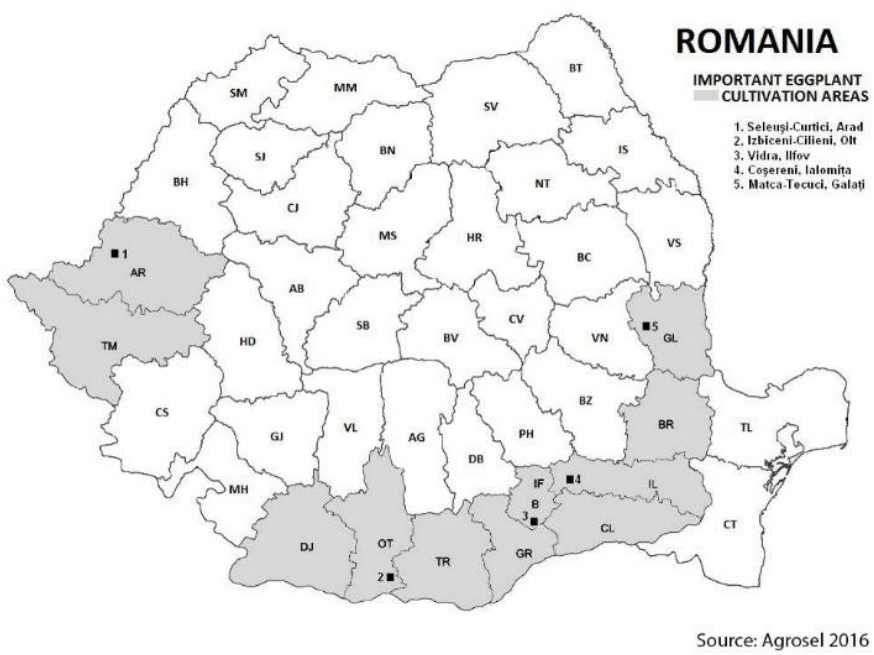

Figure 2. Important eggplant cultivation areas (AGROSEL)

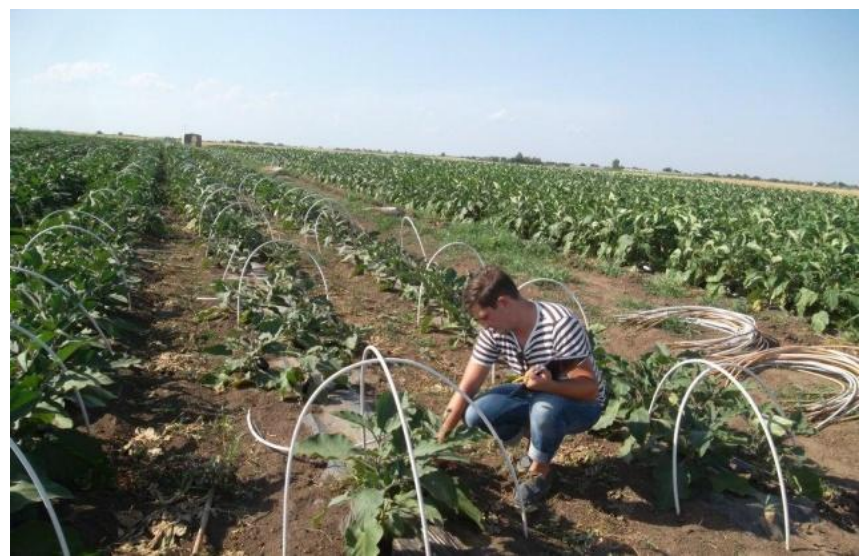

Figure 3. Open-field cultivation (AGROSEL)

For unheated greenhouse cultivation, nursing time begins about three weeks earlier; planting time begins when the air temperature remains stable at $15{ }^{\circ} \mathrm{C}$ outside the greenhouse. Eggplant production under heated greenhouses still does not exist (Ciofu R. et al. 2003). 


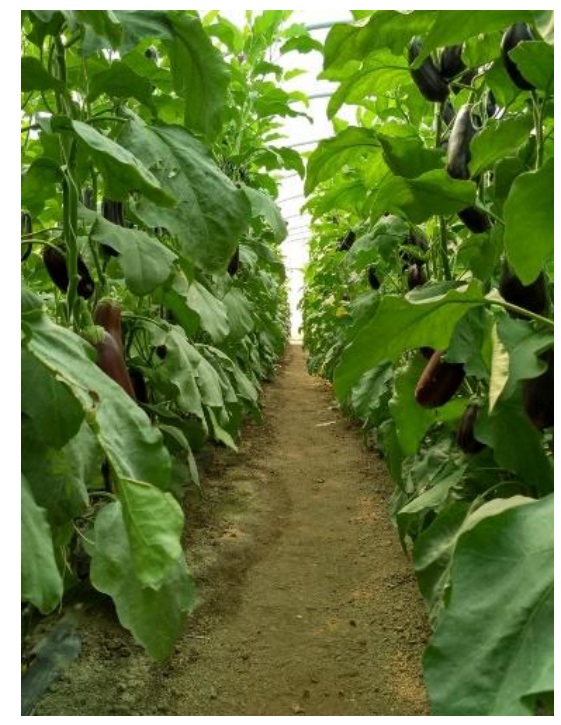

Figure 4. Unheated greenhouse cultivation (AGROSEL)

In the past, only Romanian OP varieties were grown, namely Danubiana (55-65 cm plant height, light green colour, fruit weight 240-320 g, ovoid, dark violet colour);

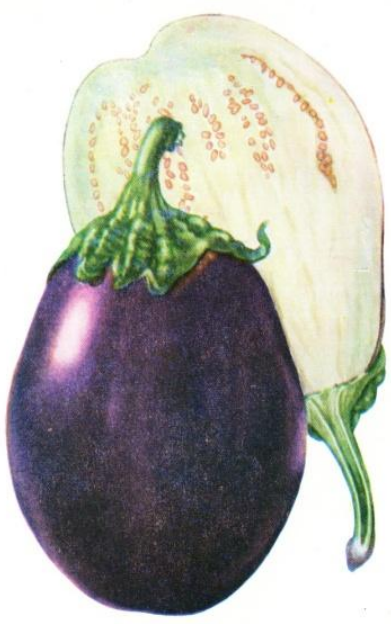

Figure 5. Danubiana variety (Andronicescu D. et al. 1970) 
Bucureștene 33 (70-80 cm plant height, grey-green colour, fruit weight 250 $300 \mathrm{~g}$, pear-shaped, dark violet-black colour);

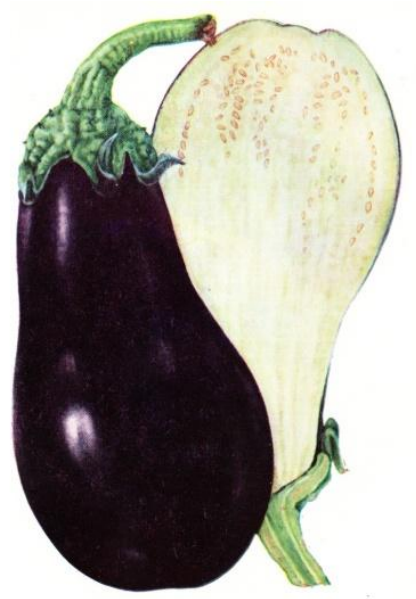

Figure 6. Bucureștene 33 variety (Andronicescu D. et al. 1970)

Pana Corbului 36 (75-85 cm plant height, green colour, fruit weight 240 $300 \mathrm{~g}$, pear-shaped, glossy dark violet-black colour);

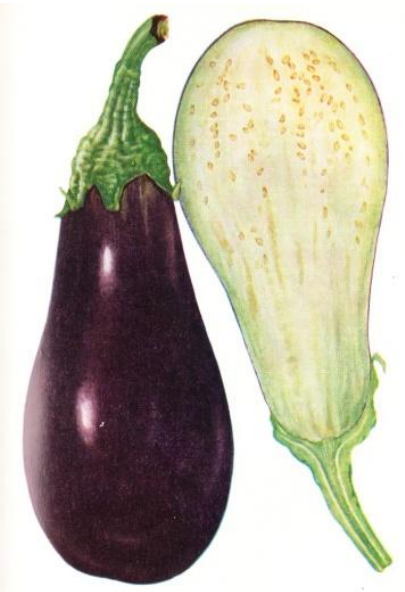

Figure 7. Pana Corbului 36 variety (Andronicescu D. et al. 1970)

Lidia (60-65 cm plant height, fruit shape obovate, glossy dark violet-black colour, tolerant to Verticillium dahlie and Phytophthora parasitica); Narcisa. In 
the 1960s, a hybrid created in Ţigăneşti, Romania, called Delicia $(70-80 \mathrm{~cm}$ plant height, violet-green colour, fruit weight 300-350 g, obovate-pear shaped, glossy dark violet-black colour, tolerant to Fusarium oxysporum f. sp. melongenae) was mentioned (Gheorghe A. et al. 1997, Andronicescu D. et al. 1970).

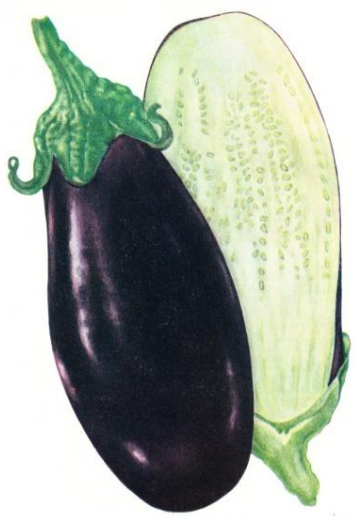

Figure 8. Delicia hybrid (Andronicescu D. et al. 1970)

Over the past ten years, requirements of eggplant varieties have increasingly shifted towards productivity, uniformity, and high tolerance to stress factors, diseases, and pests. Therefore, the cultivation of hybrids and the disappearance of Romanian OP cultivars have intensified. The most important international hybrids in Romania are: Aragon, Mirval, Classic, and Mirabelle with more or less cylindrical shaped and dark purple-black fruits. White eggplant hybrid Bibo is also becoming accepted by consumers.

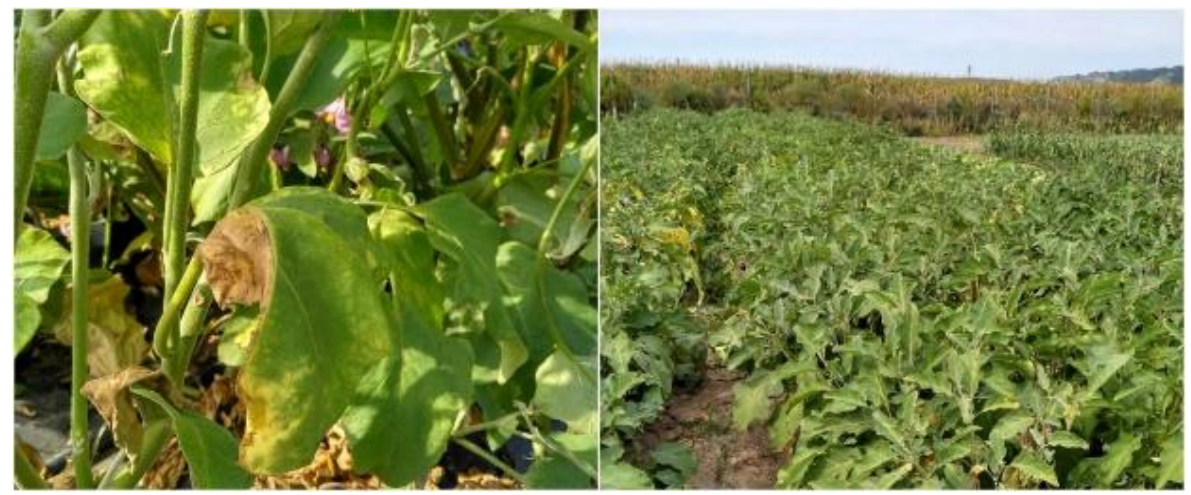

Figure 9. Infested plants (AGROSEL 1970) 
Due to monoculture practice, the soil was attacked by soil-borne pathogens and nematodes in many areas, which are very destructive in vegetable crops and can have an impact on the producers' income. Soil fumigation has been an essential component of greenhouse production since the 1960s, but it is a very expensive method. As a result, grafting (known for many years) has become necessary to be put into practice. Several trials have been carried out on grafted eggplants in Romania over the past years. The experiment in The Institute of Research and Development for Industrialization and Marketing of Horticultural Products Romania has successfully proved the advantage of this method: there was a significant reduction of infested plants, the production increased up to $34 \%$, and the quality of the harvest improved by 19\% (Bogoescu M. et al. 2014). Furthermore, another research aimed to establish the technology for obtaining the eggplant grafted seedlings by manual or mechanical grafting with a semi-automatic machine. For the manual grafting of 1,000 eggplants, 1.52 men were required per day, while when a semi-automatic machine was used only 0.16 man per day was necessary. The cost price reduction of grafting with semi-automatic machine was over 16\% (Bogoescu M. et al. 2013).

The consumption of eggplants is about $4.5 \mathrm{~kg}$ per person per year in Romania. They are consumed in many different ways such as baked, grilled, or as a special cream and they are also one of the main ingredients of the popular Balkan food, zakuszka.

Agrosel SRL has gained a significant role in supplying the Romanian vegetable seed market over the past twenty years. The company is one of the leaders in the small seed packages segment in Romania. In 2004, the firm started its own breeding programme to increase the diversity of the eggplant cultivars available in Romania.

\section{References}

[1] Al-Awwam I. (1866), The book of agriculture. Vol. 2.

[2] Sidhu A. S., Bal S. S., Behera T. K., Rani M. (2004), An outlook in hybrid eggplant breeding. Hybrid Vegetable Development, 15-29.

[3] Echim I., Jidav L., Sonea V., Voican V. (1983), Mică enciclopedie de Horticultură. Editura Enciclopedică and Ştiinţifică, Bucharest, 364-367.

[4] Andronicescu D., Perciali Gh., Avramescu A. (1970), Soiuri de legume. Editura Ceres, Bucharest, 86-93.

[5] Gheorghe A. et al. (1997), Hortus, the Romanian horticultural and viticulturist journal. Editura Tipografie, Bucharest, 71, 75.

[6] Ciofu R. et al. (2003), Tratat de legumicultură, Editura Ceres, Bucharest, 674-685.

[7] Bogoescu M., Doltu M., Moise D., Iordaghe B. (2013), Research regarding the production of eggplant grafted seedlings by manual and semi-automatic grafting. Bulletin UASVM Horticulture 70(1), 44-52. 
[8] Bogoescu M., Doltu M., Sora D. (2014), Prevention and control of soilborne diseases and nematodes in eggplants crop by grafting plants combined with soil fumigation. In: M. L. Gullino et al. (eds), Proc. of the VIIIth I.S. on Chemical and Non-Chemical Soil and Substrate Disinfestation. Acta Hort. 1044, ISHS, 331-336.

[9] http://faostat3.fao.org. 